\title{
Morphometric and Histological Changes in Cyprinid Loach, Misgurnus anguillicaudatus, in the Early Growth Period
}

\author{
Hyoung Kyun Han', Sang Gu Lim', Jung Ha Kang², Jae Wook Choi ${ }^{3}{ }^{\dagger}$ Hyun Woo Gil ${ }^{3}$, \\ Sung Hwoan $\mathrm{Cho}^{3}$, Sun-Young $\mathrm{Lim}^{3}$ and In-Seok Park ${ }^{3}$ \\ ${ }^{1}$ Inland Aquaculture Research Center, National Fisheries Research \& Development Institute, \\ Jinhae 645-758, Republic of Korea \\ ${ }^{2}$ Biotechnology Research Division, National Fisheries Research \& Development Institute, \\ Busan 619-705, Republic of Korea \\ ${ }^{3}$ Division of Marine Environment and Bioscience, College of Ocean Science and Technology, \\ Korea Maritime and Ocean University, Busan 606-791, Republic of Korea
}

\begin{abstract}
In this study, we measured the morphometric and histological changes in the cyprinid loach, Misgurnus anguillicaudatus, during the early period of growth. Eyes, yolk length, yolk height, and yolk volume of the larva decreased for 16 days post hatching $(\mathrm{DPH})(P<0.05)$. During $60 \mathrm{DPH}(P>0.05)$, the most anterior extension of the head $\times$ the posterior end of the supraoccipital, the most anterior extension of the head $\times$ the origin of the dorsal fin, the most anterior extension of the head $\times$ the origin of the pectoral fin, the posterior end of the supraoccipital $\times$ the origin of the pelvic fin, and the origin of the dorsal fin $\times$ the ventral origin of the caudal fin gradually decreased, whereas the most anterior extension of the head $\times$ the dorsal origin of the caudal fin, the origin of the dorsal fin $\times$ the origin of the anal fin, the origin of the dorsal fin $\times$ the origin of the pectoral fin, and the insertion of the dorsal fin $\times$ the origin of the pelvic fin gradually increased $(P<0.05)$. In the cyprinid loach, the retina is composed of six layers: the epithelial layer, ganglion cell layer, inner nuclear layer, inner plexiform layer, outer limiting membrane, and rod and cone layer (RCL). After hatching, part of the RCL gradually increased in density. The kidney and midgut epithelium were already formed in the cyprinid loach just after hatching and grew gradually in subsequent days.
\end{abstract}

Key words : Cyprinid loach, Early growth, Histology, Misgurnus anguillicaudatus, Morphometric trait

\section{INTRODUCTION}

Morphological differences in groups and species are classified in terms of the overall body shape or specific morphoanatomical characteristics (Sträuss \& Bond, 1990). Among the body shape characteristics of fish, morphometric traits, unlike meristic traits, can be measured as mensural characteristics. Although the body shape of fish is largely determined by genetic factors (Riddell et al., 1981; Taylor \& McPhail, 1985), the use of morphometric analyses to distinguish genetically discrete groups within a fish species is limited by the difficulty of measuring environmentally induced variations in body shape (Ihssen et al., 1981; Currens et al., 1989; Park et al., 2001).

Both truss and classical dimensions are used to describe fish body shapes (Hubbs \& Lagler, 1947; Sträuss \& Bookstein,

\footnotetext{
Manuscript received 13 August 2013, Received in revised form 20 August 2013, Accepted 29 August, 2013

'Corresponding Author : Hyun Woo Gil, Division of Marine Environment Bioscience, College of Ocean Science and Technology, Korea Maritime and Ocean University, Busan 606-791, Republic of Korea. Tel. : +82-51-410-4321, Fax : +82-51-405-4322, E-mail : ulyian1119@nate.com

This is an Open Access article distributed under the terms of the Creative Commons Attribution Non-Commercial License(http://creativecommons.org/ licenses/by-nc/3.0) which permits unrestricted non-commercial use, distribution, and reproduction in any medium, provided the original work is properly cited.
} 
1982). Truss dimensions consist of a systematically arranged set of distances that are measured between a set of preselected anatomical landmarks (Sträuss \& Bookstein, 1982; Sträuss \& Bond, 1990). These landmarks are identified based on local morphological features and are chosen to divide the body into functional units (Sträuss \& Bond, 1990). Truss dimensions, which include components of body depth and length along the longitudinal axis, have theoretical advantages over classical morphometric characteristics in discriminating different groups (Park et al., 2007).

The cyprinid loach, Misgurnus anguillicaudatus, is a freshwater fish species of the loach family Cobitidae (Nelson, 2006). The species is native to East Asia, but is also popular as an aquarium fish and has been introduced elsewhere in Asia and to Europe and North America (Park et al., 2006c). The cyprinid loach inhabits mud, ponds, and rice fields, which are subject to periodic drying (Park \& Kim, 2000), and this can result in starvation. The domestic market for this species has expanded rapidly in recent years, and consequently, the cyprinid loach is now a commercially important freshwater species in Korea (Park et al., 2006c). Therefore, it is cultivated in Korea with high marketability. However, our knowledge of the early larval development of the cyprinid loach is limited.

The visual function of fish larvae is very important for feeding, positioning, collective behavior, and escape from predators (Rodriguez \& Gisbert, 2001; Park et al., 2006a). The retinal structure of the Teleostei is not distinct from the retinal structure of vertebrates. However, although it is comparable to that of other vertebrates, it is difficult to propose a general retinal structure for the Teleostei because of the many species, various habitat, numerous activities, and different life cycle in this taxon (Wagner, 1990). The structure and function of the visual apparatus, the behavior of the organism, and environmental influences are very important factors in visual ecology (Walls, 1942; Lythgoe, 1979).

It is well recognized that to successfully rear larval fish, the culture conditions, feeding strategies, and survival rates must be considered in terms of the ontogenetic status of the larvae. The early survival rates of marine fish are influenced by the success or failure of the first feeding, with the transition from endogenous feeding to exogenous feeding after the reduction of the yolk sac (O'Connell, 1976; Theilacker, 1978; Strussmann \& Takshima, 1990). Thus, it is important to understand the development of the alimentary tract tissues, organogenesis, and the time at which the yolk sac is completely absorbed during growth to increase the early survival rate of fish.

More information about the developmental stages of the cyprinid loach is required because high levels of hatchery mortality are common during the early life stages of reared larvae. However, there have been no detailed reports of the anatomy of this species other than those describing the morphological and histological changes that occur in cyprinid loach larvae (Park \& Kim, 2000; Park et al., 2006b). Because research into the early larval development of the cyprinid loach is currently insufficient, in this study, we investigated the process of yolk absorption in $M$. anguillicaudatus, determined the changes in its morphometric characteristics, and observed the histological changes that occur in the retina, kidney, and midgut epithelium.

\section{MATERIALS AND METHODS}

We used larval specimens of the cyprinid loach, $M$. anguillicaudatus $(n=30)$ that hatched on June 28, 2012. We obtained fertilized eggs from Southern Island Fishery Research Institute of the National Fisheries Research and Development Institute (NFRDI) in Korea. They were reared and bred in the Laboratory for Fisheries Genetics and Breeding Sciences, Korea Maritime and Ocean Uni-

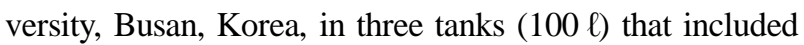
a circulation pump, an aeration system, and a temperaturecontrol system. Dissolved oxygen levels were maintained with an air pump and the water temperature was maintained at $26 \pm 0.5^{\circ} \mathrm{C}$. Standard length of female and male were $15.6 \pm 1.88 \mathrm{~cm}$ and $16.1 \pm 1.42 \mathrm{~cm}$ respectively. Body weight of female and male were $10.2 \pm 0.43 \mathrm{~g}$ and $10.4 \pm 0.49 \mathrm{~g}$, 
respectively.

To measure the eye diameter, yolk length (YL), yolk height (YH), and yolk volume (YV), we fixed 50 larval cyprinid loaches, ranging in age from just hatched to 16 days posthatching (DPH), in 10\% neutral formalin for two days. We also measured the larvae of the cyprinid loach in the yolk stage to the nearest $1 \mathrm{~mm}$, using the scale and Vernier calipers (CD-20CP; Mitutoyo, Japan). We measured $\mathrm{YL}$ and $\mathrm{YH}$ according to number of days after hatching; and YV was measured with the mathematical formula $\mathrm{YV}=(\pi / 2) \times \mathrm{a} \times \mathrm{b},{ }^{2}$ where $\mathrm{a}$ is yolk length, $\mathrm{b}$ is yolk height (Blaxter \& Hempel, 1963).

To determine the morphometric characteristics of the cyprinid loach, 30 samples were randomly selected at 10-day intervals from $20 \mathrm{DPH}$ to $60 \mathrm{DPH}$ and fixed in $10 \%$ neutral formalin. Body outline measurements were made for 25 distances between the landmarks used for both truss and classical dimensions (Table 1, Fig. 1). We measured the larvae each day to the nearest $1 \mathrm{~mm}$ using the scale and Vernier calipers, and their weights were measured with an electronic balance. The horizontal distance measurements made were: Ls, standard length; HHAV, horizontal distance between the most anterior extension of the head and the anterior insertion of the ventral fin; HHAP, horizontal distance between the most anterior extension of the head and the anterior insertion of the pectoral fin; HDAC, horizontal distance between the most anterior extension of the anal fin and the anterior insertion of the caudal fin; and ED, eye diameter. The other distances (truss morphometric dimensions and classical morphometric dimensions) were determined from the direct distance measurements.

The external truss morphometric dimensions were $2 \times$ 3 , the posterior end of the supraoccipital $\times$ the origin of the dorsal fin; $2 \times 10$, the posterior end of the supraoccipital $\times$ the origin of the pelvic fin; $2 \times 11$, the posterior end of the supraoccipital $\times$ the origin of the pectoral fin; $3 \times 4$, the origin of the dorsal fin $\times$ the insertion of the dorsal fin; $3 \times 7$, the origin of the dorsal fin $\times$ the ventral origin of the caudal fin; $3 \times 8$, the origin of the dorsal fin $\times$ the insertion of the anal fin; $3 \times 9$, the origin of the dorsal fin $\times$ the origin of the anal fin; $3 \times 10$, the origin of the dorsal fin $\times$ the origin of the pelvic fin; $3 \times 11$, the origin of the dorsal fin $\times$ the origin of the pectoral fin; $4 \times 7$, the insertion of the dorsal fin $\times$ the ventral origin of the caudal fin; $4 \times 8$, the insertion of the dorsal fin $\times$ the insertion of the anal fin; $4 \times 9$, the insertion of the dorsal fin $\times$ the origin of the anal fin; $4 \times 10$, the insertion of the dorsal fin $\times$ the origin of the pelvic fin; $4 \times 11$, the insertion of the dorsal fin $\times$ the origin of the pectoral fin; and $5 \times$ 7 , the dorsal origin of the caudal fin $\times$ the ventral origin of the caudal fin (Fig. 1). Each external morphometric dimension was analyzed relative to $L s$.

The external classical morphometric dimensions were: $1 \times 2$, the most anterior extension of the head $\times$ the posterior end of the supraoccipital; $1 \times 3$, the most anterior extension of the head $\times$ the origin of the dorsal fin; $1 \times$ 5 , the most anterior extension of the head $\times$ the origin of the caudal fin; $1 \times 9$, the most anterior extension of the head $\times$ the origin of the anal fin; $1 \times 10$, the most anterior extension of the head $\times$ the origin of the pelvic fin; $1 \times$ 11 , the most anterior extension of the head $\times$ the origin of the pectoral fin; and $1 \times 12$, the most anterior extension of the head $\times$ the most posterior aspect of the operculum (Fig. 1). Each external morphometric dimension was analyzed relative to $L s$.

To observe the organogenesis of the cyprinid loach, 30 samples were randomly selected at 10-day intervals from just hatched to $50 \mathrm{DPH}$ and fixed in $10 \%$ neutral formalin. We extracted the eye, kidney, and midgut epithelium from the fish sampled at just hatched, $10 \mathrm{DPH}, 30 \mathrm{DPH}$, and $50 \mathrm{DPH}$ for histological analysis. Each sample was fixed in Bouin's solution for $24 \mathrm{~h}$ and then washed in flowing water. To decalcify the samples, they were processed in decalcification solution for $24 \mathrm{~h}$ and washed again. The samples were then dehydrated in a graded series of alcohol: successively in $70 \%, 80 \%, 90 \%$, and $100 \%$ alcohol for $1 \mathrm{~h}$ each. After they were cleared with xylene for impregnation, the samples were treated with soft paraffin and hard paraffin, embedded, trimmed, and 
HK Han, SG Lim, JH Kang, JW Choi, HW Gil, SH Cho, S-Y Lim, I-S Park

Table 1. Morphometric dimensions of the cyprinid loach, Misgurnus anguillicaudatus, determined in this experiment*

\begin{tabular}{|c|c|}
\hline \multicolumn{2}{|l|}{ Morphometric dimensions } \\
\hline \multicolumn{2}{|l|}{ Horizontal distance } \\
\hline Standard length $(L s)$ & $1 \times 6$ \\
\hline Horizontal distance between the most anterior extension of the head and the anterior insertion of the ventral fin & HHAV \\
\hline Horizontal distance between the most anterior extension of the head and the anterior insertion of the pectoral fin & HHAP \\
\hline Horizontal distance between the most anterior extension of the anal fin and the anterior insertion of the caudal fin & HDAC \\
\hline Eye diameter & ED \\
\hline \multicolumn{2}{|l|}{ Direct distance } \\
\hline \multicolumn{2}{|l|}{ Truss dimension } \\
\hline Posterior end of supraoccipital $\times$ origin of dorsal fin & $2 \times 3$ \\
\hline Posterior end of supraoccipital $\times$ origin of pelvic fin & $2 \times 10$ \\
\hline Posterior end of supraoccipital $\times$ origin of pectoral fin & $2 \times 11$ \\
\hline Origin of dorsal fin $\times$ insertion of dorsal fin & $3 \times 4$ \\
\hline Origin of dorsal fin $\times$ ventral origin of caudal fin & $3 \times 7$ \\
\hline Origin of dorsal fin $\times$ insertion of anal fin & $3 \times 8$ \\
\hline Origin of dorsal fin $\times$ origin of anal fin & $3 \times 9$ \\
\hline Origin of dorsal fin $\times$ origin of pelvic fin & $3 \times 10$ \\
\hline Origin of dorsal fin $\times$ origin of pectoral fin & $3 \times 11$ \\
\hline Insertion of dorsal fin $\times$ ventral origin of caudal fin & $4 \times 7$ \\
\hline Insertion of dorsal fin $\times$ insertion of anal fin & $4 \times 8$ \\
\hline Insertion of dorsal fin $\times$ origin of anal fin & $4 \times 9$ \\
\hline Insertion of dorsal fin $\times$ origin of pelvic fin & $4 \times 10$ \\
\hline Insertion of dorsal fin $\times$ origin of pectoral fin & $4 \times 11$ \\
\hline Dorsal origin of caudal fin $\times$ ventral origin of caudal fin & $5 \times 7$ \\
\hline \multicolumn{2}{|l|}{ Classical dimension } \\
\hline Most anterior extension of the head $\times$ posterior end of supraoccipital & $1 \times 2$ \\
\hline Most anterior extension of the head $\times$ origin of dorsal fin & $1 \times 3$ \\
\hline Most anterior extension of the head $\times$ dorsal origin of caudal fin & $1 \times 5$ \\
\hline Most anterior extension of the head $\times$ origin of anal fin & $1 \times 9$ \\
\hline Most anterior extension of the head $\times$ origin of pelvic fin & $1 \times 10$ \\
\hline Most anterior extension of the head $\times$ origin of pectoral fin & $1 \times 11$ \\
\hline Most anterior extension of the head $\times$ most posterior aspect of operculum & $1 \times 12$ \\
\hline
\end{tabular}

* Each dimension is illustrated in Fig. 1.

sectioned. The sections were then stained with hematoxylineosin and mounted with Canadian balsam. After we had determined the critical points of the samples, we photographed them with an optical microscope equipped with a camera (Axiocam MR, Carl Zeiss, Germany).

Using an eyepiece micrometer under an optical microscope (Axiocam MR), we used the methods of Park et al. (2006c) to measure the thickness of the retina; the epithelial layer (EL), the rod and cone layer (RCL), the outer limiting membrane layer (OLM), the inner nuclear layer (INL), the inner plexiform layer (IPL), and the ganglion cell layer (GCL). We also photographed the eye structure of the larvae from just-hatched to $50 \mathrm{DPH}$ using an optical microscope. To analyze the development of the kidney and midgut epithelium, we used the Axioskop 4.1 image analysis software (Carl Zeiss, Germany) to measure the areas and volumes of the cells and nuclei using the following formulae: surface area $=1 / 4 \times a b \pi$, and volume $=4 / 3 \times \pi(a / 2) \times(b / 2)^{2}$, where $a$ is the major axis of the cell or nucleus; and $b$ is the minor axis of the 
A
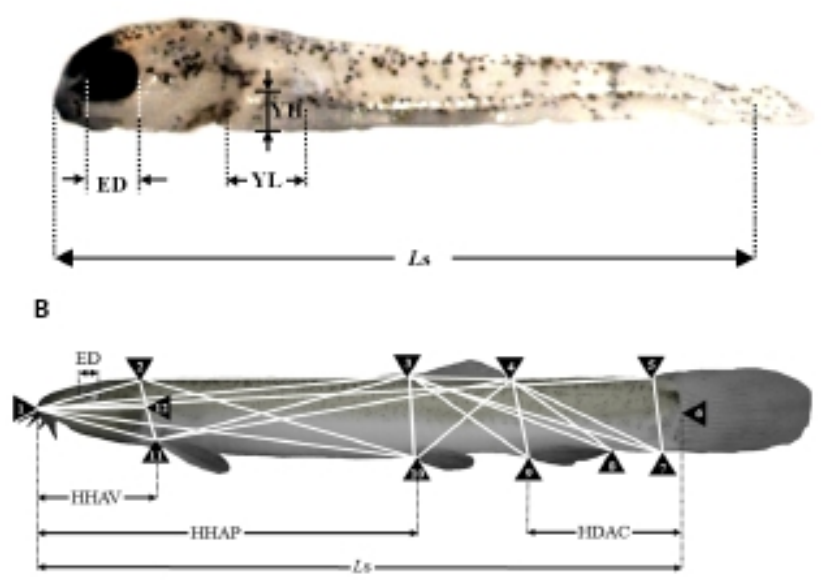

Fig. 1. Morphometric measurements between the landmarks of the cyprinid loach, Misgurnus anguillicaudatus, used in this study. Larva in the yolk stage (A) and juvenile (B) of the cyprinid loach. For abbreviations, see Table 1. YL: yolk length; YH: yolk height; ED: eye diameter; HHAV: horizontal distance between the most anterior extension of the head and the anterior insertion of the ventral fin; HHAP: horizontal distance between the most anterior extension of the head and the anterior insertion of the pectoral fin; HDAC: horizontal distance between the most anterior extension of the anal fin and the anterior insertion of the caudal fin; Ls: standard length.

cell or nucleus (Park \& Kim, 2000).

The experiment was performed in triplicate and the results are reported as means $\pm S D(n=30)$, unless otherwise stated. The data were analyzed with one-way ANOVA using the SPSS statistical package (SPSS 9.0, SPSS Inc., Chicago, IL, USA). Means were compared using Duncan's multiple range test and were considered significantly different at $P<0.05$.

\section{RESULTS}

Table 2 shows the one morphometric dimension and three morphometric dimensions/Ls of the cyprinid loach, Misgurnus anguillicaudatus, ranging in age from just hatched to $16 \mathrm{DPH}$. At $1 \mathrm{DPH}$, the eye was 30.4. Thereafter, the eye ratio decreased to 7.8 at $16 \mathrm{DPH}$. YL also decreased from 18.4 to 2.7 at $16 \mathrm{DPH}$. YH gradually decreased from 7.7 to 1.7 at $16 \mathrm{DPH}(P<0.05)$. During the experimental period from $1 \mathrm{DPH}$ to $16 \mathrm{DPH}$, YL was always greater than YH $(P<0.05)$. YV decreased most rapidly of all the values to $16 \mathrm{DPH}$.

Figures 2 and 3 show growth curves for the cyprinid loach. The increase in $L \mathrm{~s}$ was $\mathrm{y}=0.1 \mathrm{x}+0.48, R^{2}=0.8777$ (y is standard length in $\mathrm{mm} x$ is $\mathrm{DPH}$ ); the increase in body weight was $\mathrm{y}=10.9 \mathrm{x}-18.80, R^{2}=0.8552$ ( $\mathrm{y}$ is body weight in $\mathrm{mg} x$ is $\mathrm{DPH}$ ). The increases in standard length and body weight showed a positive relationship. Standard length increased to $0.7 \mathrm{~mm}$ from $30 \mathrm{DPH}$ to 50

Table 2. Results of the Duncan multiple range test for differences in three characteristics for cyprinid loach, Misgurnus anguillicaudatus from hatching to 14 days post hatched*

\begin{tabular}{|c|c|c|c|c|}
\hline \multirow{3}{*}{$\begin{array}{l}\text { Days post } \\
\text { hatched }\end{array}$} & \multicolumn{4}{|c|}{ Morphometric dimension } \\
\hline & \multirow{2}{*}{ ED } & \multicolumn{3}{|c|}{ Yolk dimension/Ls (\%) } \\
\hline & & Length & Height & Volume \\
\hline Just hatch & $30.4 \pm 2.46^{\mathrm{A}}$ & $18.4 \pm 3.98^{\mathrm{A}}$ & $7.7 \pm 1.55^{\mathrm{A}}$ & $45.1 \pm 2.29^{\mathrm{A}}$ \\
\hline 2 & $28.6 \pm 2.36^{\mathrm{B}}$ & $14.7 \pm 6.50^{\mathrm{B}}$ & $6.3 \pm 1.01^{\mathrm{B}}$ & $35.0 \pm 3.86^{\mathrm{B}}$ \\
\hline 4 & $24.5 \pm 1.24^{\mathrm{C}}$ & $12.9 \pm 2.92^{\mathrm{C}}$ & $5.5 \pm 1.46^{\mathrm{C}}$ & $32.9 \pm 1.14^{\mathrm{C}}$ \\
\hline 6 & $22.7 \pm 1.91^{\mathrm{D}}$ & $10.1 \pm 1.10^{\mathrm{D}}$ & $4.5 \pm 0.96^{\mathrm{D}}$ & $28.6 \pm 2.58^{\mathrm{D}}$ \\
\hline 8 & $17.6 \pm 1.67^{\mathrm{E}}$ & $6.8 \pm 4.17^{\mathrm{E}}$ & $4.1 \pm 0.80$ & $22.2 \pm 4.10^{\mathrm{E}}$ \\
\hline 10 & $12.0 \pm 3.72^{\mathrm{F}}$ & $5.5 \pm 3.66^{\mathrm{F}}$ & $3.8 \pm 0.72^{\mathrm{F}}$ & $18.0 \pm 2.33^{\mathrm{F}}$ \\
\hline 12 & $9.4 \pm 1.84^{\mathrm{G}}$ & $4.7 \pm 2.25^{\mathrm{G}}$ & $3.1 \pm 0.45^{\mathrm{G}}$ & $15.3 \pm 1.36^{\mathrm{G}}$ \\
\hline 14 & $8.6 \pm 3.77^{\mathrm{H}}$ & $3.4 \pm 3.73^{\mathrm{H}}$ & $2.1 \pm 0.35^{\mathrm{H}}$ & $14.3 \pm 1.25^{\mathrm{H}}$ \\
\hline 16 & $7.8 \pm 1.09^{\mathrm{I}}$ & $2.7 \pm 2.83^{\mathrm{I}}$ & $1.7 \pm 0.54^{\mathrm{I}}$ & $13.4 \pm 1.25^{\mathrm{I}}$ \\
\hline
\end{tabular}

* Data were analyzed using one- and two-way ANOVA on data transformed to the arcsine of the square root. Different capital letters on the values indicate statistical significance among day after hatched $(P<0.05)$. ED: eye diameter. Volume $=(\pi / 2) \times a \times b^{2}(a$ is yolk length, b is yolk height, after Blaxter and Gempel, 1963). 
DPH. Thereafter, the cyprinid loach grew to $2.27 \mathrm{~mm}$ (Fig. 2) and its body weight increased to $90.2 \mathrm{mg}$ at a steady rate to $60 \mathrm{DPH}$ (Fig. 2). The rate of increase in body weight was more regular than the increase in standard length (Fig. 2). The body weight/standard length relationship was $\mathrm{y}=38.8 \mathrm{x}-16.79, R^{2}=0.8478$ (y is body weight in $\mathrm{mg} x$ is standard length in mm) (Fig. 3). Body weight and standard length increased proportionally (Fig. 3). Although the average body weight/standard length ratio was 38.8, body weight/standard length in the point of standard length $0.65-1 \mathrm{~mm}$ was 14.28 , and $1.25-1.55$ $\mathrm{mm}$ was 20, which indicates a slower increase in body weight than in standard length (Fig. 3).

Table 3 show 26 morphometric dimensions/Ls of the cyprinid loach, measured every 10 days from $20 \mathrm{DPH}$ to 60 DPH: $2 \times 11,4 \times 8$, and $4 \times 9$ did not differ significantly from $30 \mathrm{DPH}$ to $60 \mathrm{DPH}(P>0.05)$, and $3 \times 4,3 \times 8$, and $3 \times 10$ did not differ significantly from $40 \mathrm{DPH}$ to 60 DPH. During the $60 \mathrm{DPH}, 1 \times 2,1 \times 3,1 \times 11,2 \times 10$, and $3 \times 7$ decreased gradually $(P>0.05)$, whereas $1 \times 5$, 3 $\times 9,3 \times 11$, and $4 \times 10$ increased gradually $(P<0.05) ; 3 \times$ 11 and $2 \times 3$ increased by $11 \%$ and $9 \%$, respectively, and this was the greatest growth rate in the external characteristics of the fish, occurring in a section of fin $(P<$ 0.05). As shown in Fig. 4, the patterns of increase in the morphometric characteristics measured in this study can be classified in three ways. HHAV, $1 \times 3$, and $1 \times 9$ are the main traits of each curve (Fig. 4). In the point of standard length $1.78 \mathrm{~mm}$ the length of each dimensions of $1 \times 3$ series were only changed. At the same point, the other series of curves gradually increased (Fig. 4).

Table 4 shows the component layers of the retina in the cyprinid loach from just hatched to $50 \mathrm{DPH}$. The thickness of the retina decreased from just hatched to 10 $\mathrm{DPH}$, but increased continuously thereafter to $50 \mathrm{DPH}$ $(P<0.05)$. The thickness of the RCL increased most rapidly, whereas GCL decreased most dramatically of all the component layers over 50 days $(P<0.05)$. Table 5 shows the cell sizes of the proximal tubule in the kidney and the nuclear height of the cells of the midgut epithelium in the fish from hatching to $50 \mathrm{DPH}$. The nuclear height of the midgut epithelium increased continuously from
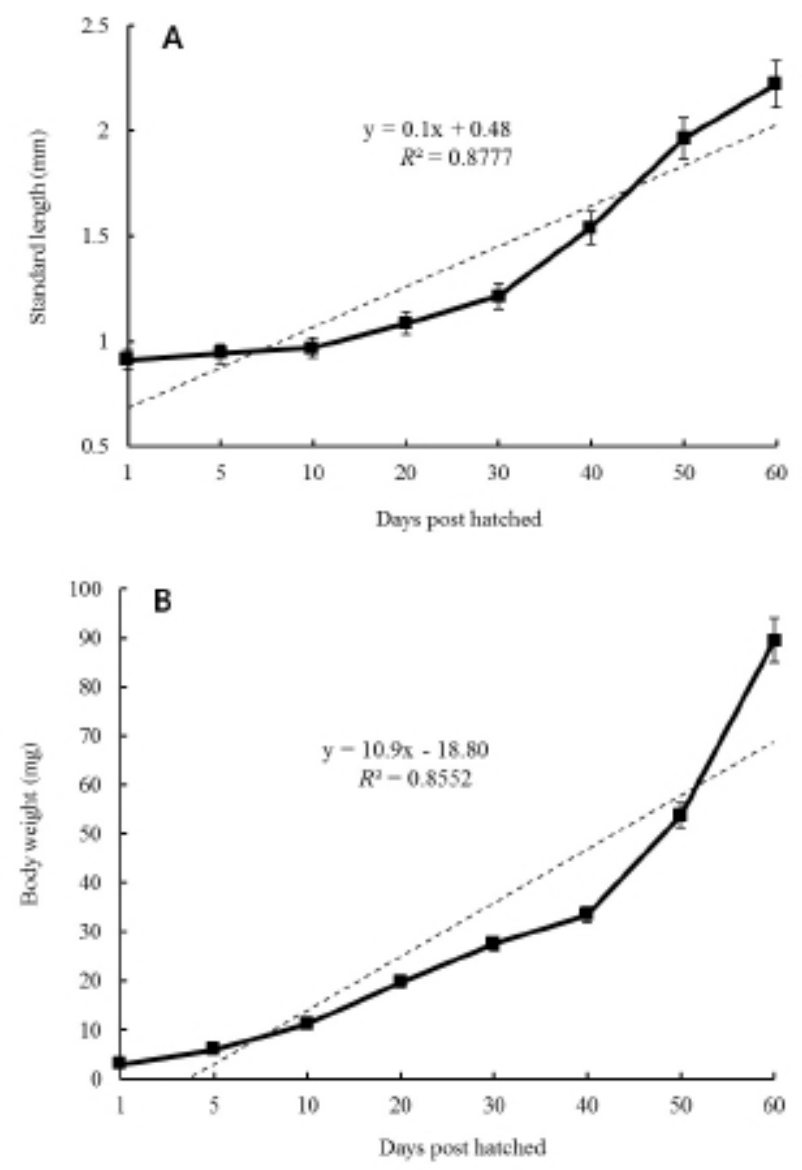

Fig. 2. The growth curves for standard length (A) and body weight (B) for the cyprinid loach, Misgurnus anguillicaudatus, in the early period of growth.

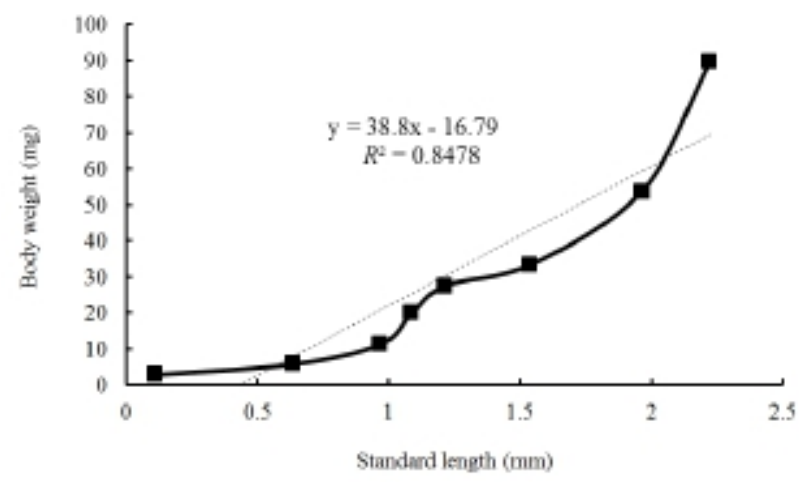

Fig. 3. The relationship between standard length and body weight in the cyprinid loach, Misgurnus anguillicaudatus, from hatching to 60 days after hatching. 
Morphometric and Histological Changes in Cyprinid Loach in Early Growth Period

Table 3. Differences in 26 characteristics of cyprinid loach, Misgurnus anguillicaudatus, by days after hatching, determined with Duncan's multiple range test*

\begin{tabular}{|c|c|c|c|c|c|}
\hline \multirow{2}{*}{$\begin{array}{c}\text { Morphometric } \\
\text { dimension/Ls (\%) }\end{array}$} & \multicolumn{5}{|c|}{ Days after hatching } \\
\hline & 20 & 30 & 40 & 50 & 60 \\
\hline HHAV & $71.4 \pm 3.72^{\mathrm{Ac}}$ & $69.5 \pm 1.68^{\mathrm{BC}}$ & $67.1 \pm 3.84^{\mathrm{Cc}}$ & $65.7 \pm 4.88^{\mathrm{Dc}}$ & $63.8 \pm 2.81^{\mathrm{Ec}}$ \\
\hline HHAA & $34.3 \pm 4.28^{\mathrm{Ag}}$ & $32.6 \pm 4.28^{\mathrm{Bg}}$ & $30.4 \pm 4.28^{\mathrm{Cg}}$ & $28.2 \pm 4.28^{\mathrm{Dg}}$ & $28.9 \pm 4.28^{\mathrm{Dg}}$ \\
\hline HDMC & $25.5 \pm 3.35^{\mathrm{Ah}}$ & $24.7 \pm 3.35^{\mathrm{Bh}}$ & & $\mathrm{Dh}$ & $22.3 \pm 3.35^{\mathrm{Dh}}$ \\
\hline $1 \times 2$ & $32.2 \pm 3.82^{\mathrm{Ah}}$ & $28.4 \pm 3.12^{\mathrm{bg}}$ & & Dg & $22.5 \pm 4.67^{\mathrm{Eg}}$ \\
\hline $1 \times 3$ & $32.4 \pm 3.30 \mathrm{Ag}$ & $64.8 \pm 2.34^{\mathrm{Bc}}$ & & Dc & $58.1 \pm 3.41^{\mathrm{Dc}}$ \\
\hline $1 \times 5$ & $95.2 \pm 2.39$ đᄃ & $96.1 \pm 3.74^{\mathrm{Ba}}$ & $97.6 \pm 2.11^{\mathrm{Ca}}$ & $97.7 \pm 1.18^{\mathrm{Ca}}$ & $97.6 \pm 5.68^{\mathrm{Ca}}$ \\
\hline $1 \times 9$ & $80.9 \pm 2.35^{\mathrm{Ab}}$ & $79.4 \pm 3.81^{\mathrm{Bb}}$ & & $\mathrm{Cb}$ & $78.9 \pm 4.44^{\mathrm{Cb}}$ \\
\hline $1 \times 10$ & $68.6 \pm 5.56$ Ac & $66.7 \pm 3.87^{\mathrm{BC}}$ & $700+117$ & Dc & $64.1 \pm 4.43^{D c}$ \\
\hline $1 \times 11$ & $4 \mathrm{Y} .2 \pm 2.38 \mathrm{A \complement}$ & $32.2 \pm 2.38^{\mathrm{Be}}$ & & De & $30.2 \pm 2.38^{\mathrm{De}}$ \\
\hline $1 \times 12$ & $31.4 \pm 2.02^{\mathrm{Ag}}$ & $28.5 \pm 2.42^{\mathrm{bg}}$ & & $\mathrm{Cg}$ & $27.3 \pm 2.67^{\mathrm{Cg}}$ \\
\hline $2 \times 3$ & $22.3 \pm 2.85^{\text {Re }}$ & $24.8 \pm 3.64^{\mathrm{Bd}}$ & $46.1 \pm 4.18^{\mathrm{Cd}}$ & $46.4 \pm 4.31^{\mathrm{Cd}}$ & $46.2 \pm 4.11^{\mathrm{Cd}}$ \\
\hline $2 \times 10$ & $58.9 \pm 2.51^{\mathrm{Ad}}$ & $48.1 \pm 4.84^{\mathrm{Bd}}$ & & $\mathrm{Cd}$ & $47.2 \pm 2.01^{\mathrm{Cd}}$ \\
\hline $2 \times 11$ & $15.6 \pm 2.18$ & $14.8 \pm 3.14^{\mathrm{Bk}}$ & $17 \cap+100$ & $\mathrm{Bk}$ & $14.7 \pm 4.44^{\mathrm{Bk}}$ \\
\hline $3 \times 4$ & $16.1 \pm 2.51^{\mathrm{Ak}}$ & $16.0 \pm 1.55^{\mathrm{Ak}}$ & $14.3 \pm 1.89^{\mathrm{Bk}}$ & $14.4 \pm 2.00^{\mathrm{Bk}}$ & $14.4 \pm 2.29^{\mathrm{Bk}}$ \\
\hline $3 \times 7$ & $54.0 \pm 2.39^{\mathrm{Ad}}$ & $44.5 \pm 4.85^{\mathrm{Bd}}$ & $38.2 \pm 2.61^{\mathrm{Ce}}$ & $38.4 \pm 1.64^{\mathrm{Ce}}$ & $38.6 \pm 2.93^{\mathrm{Ce}}$ \\
\hline $3 \times 8$ & $28.5 \pm 1.23^{\mathrm{Ag}}$ & $28.4 \pm 3.14^{\mathrm{Ag}}$ & $29.1 \pm 5.02^{\mathrm{Bg}}$ & $29.6 \pm 4.44^{\mathrm{Bg}}$ & $29.4 \pm 4.99^{\mathrm{Bg}}$ \\
\hline $3 \times 9$ & $20.8 \pm 4.48^{\mathrm{Al}}$ & $20.5 \pm 3.88^{\mathrm{Al}}$ & $21.9 \pm 2.22^{\mathrm{Bl}}$ & $22.9 \pm 3.66^{\mathrm{Ci}}$ & $23.0 \pm 4.10^{\mathrm{Ci}}$ \\
\hline $3 \times 10$ & $14.9 \pm 4.18^{\mathrm{Ak}}$ & $14.8 \pm 3.77^{\mathrm{Ak}}$ & $13.1 \pm 2.84^{\mathrm{Bk}}$ & $13.2 \pm 4.00^{\mathrm{Bk}}$ & $13.7 \pm 3.08^{B k}$ \\
\hline $3 \times 11$ & $37.9 \pm 1.68^{\mathrm{At}}$ & $39.8 \pm 2.88^{\mathrm{Bt}}$ & $40.5 \pm 4.19^{\mathrm{Ct}}$ & $41.4 \pm 5.22^{\mathrm{Df}}$ & $42.1 \pm 4.16^{\mathrm{Ef}}$ \\
\hline $4 \times 7$ & $31.4 \pm 4.02^{\mathrm{Ag}}$ & $28.2 \pm 4.42^{\mathrm{Bg}}$ & $28.1 \pm 5.12^{\mathrm{Bg}}$ & $27.7 \pm 1.72^{\mathrm{Cg}}$ & $27.5 \pm 4.18^{\mathrm{Cg}}$ \\
\hline $4 \times 8$ & $22.7 \pm 1.90^{\mathrm{Al}}$ & $21.4 \pm 3.93^{\mathrm{Bi}}$ & $21.5 \pm 1.29^{\mathrm{Bi}}$ & $21.8 \pm 3.74^{\mathrm{Bi}}$ & $21.9 \pm 3.27^{\mathrm{Bi}}$ \\
\hline $4 \times 9$ & $13.4 \pm 4.95^{\mathrm{Ak}}$ & $14.5 \pm 3.18^{\mathrm{Bk}}$ & & $\mathrm{Bk}$ & $14.9 \pm 3.11^{\mathrm{Bk}}$ \\
\hline $4 \times 10$ & $18.3 \pm 4.75^{\mathrm{Ak}}$ & $19.6 \pm 2.51^{\mathrm{bj}}$ & $20.2 \pm 3.80^{\mathrm{Cj}}$ & $20.5 \pm 4.28^{\mathrm{Cj}}$ & $20.1 \pm 1.91^{\mathrm{Cj}}$ \\
\hline $4 \times 11$ & $52.3 \pm 4.93^{\mathrm{Ad}}$ & $51.4 \pm 2.47^{\mathrm{Bd}}$ & $50.5 \pm 1.85^{\mathrm{Cd}}$ & $50.6 \pm 5.91^{\mathrm{Cd}}$ & $50.1 \pm 4.02^{\mathrm{Cd}}$ \\
\hline $5 \times 7$ & $11.6 \pm 0.36^{\mathrm{An}}$ & $9.4 \pm 0.97^{\mathrm{Bn}}$ & $7.6 \pm 1.21^{\mathrm{cn}}$ & $7.6 \pm 1.19^{\mathrm{Cn}}$ & $7.6 \pm 1.01^{\mathrm{Cn}}$ \\
\hline ED & $7.6 \pm 1.01^{\text {Ао }}$ & $6.9 \pm 0.92^{\text {Bo }}$ & $5.7 \pm 0.88^{\mathrm{Cn}}$ & $4.6 \pm 0.54^{\mathrm{Cn}}$ & $4.5 \pm 0.78^{\mathrm{Cn}}$ \\
\hline
\end{tabular}

* For the abbreviations and each dimension, see Table 1 and Fig. 1. Data were analyzed using one- and two-way ANOVA after transformation to the arcsine of the square root. Different capital letters on the values indicate a statistically significant difference among days after hatching $(P<0.05)$. Different small letters on the values indicate a statistically significant difference among the morphometric dimensions/Ls $(P<0.05)$.

Table 4. Thickness of each component layer of the retina of the cyprinid loach, Misgurnus anguillicaudatus, from hatching to 50 days after hatching*

\begin{tabular}{lcccc}
\hline & \multicolumn{4}{c}{ Days after hatching } \\
\cline { 2 - 5 } & 0 & 10 & 30 & 50 \\
\hline Thickness of 1retina ( ) & $92.4 \pm 3.23^{\mathrm{a}}$ & $97.2 \pm 4.76^{\mathrm{a}}$ & $110.4 \pm 6.03^{\mathrm{b}}$ & $147.0 \pm 9.78^{\mathrm{c}}$ \\
& Thickness of each layer of retina (\%) & & \\
Epithelial layer & $3.8 \pm 0.22^{\mathrm{a}}$ & $4.1 \pm 0.21^{\mathrm{ab}}$ & $4.3 \pm 0.29^{\mathrm{b}}$ & $5.1 \pm 0.36^{\mathrm{c}}$ \\
Rod and cone layer & $8.6 \pm 0.47^{\mathrm{a}}$ & $9.7 \pm 0.74^{\mathrm{b}}$ & $12.1 \pm 0.99^{\mathrm{c}}$ & $20.7 \pm 1.20^{\mathrm{d}}$ \\
Outer limiting membrane layer & $4.2 \pm 0.33^{\mathrm{a}}$ & $4.3 \pm 0.28^{\mathrm{a}}$ & $5.1 \pm 0.29^{\mathrm{ab}}$ & $6.7 \pm 0.33^{\mathrm{b}}$ \\
Inner nuclear layer & $10.1 \pm 0.44^{\mathrm{a}}$ & $8.9 \pm 0.24^{\mathrm{b}}$ & $7.6 \pm 0.36^{\mathrm{bc}}$ & $7.5 \pm 0.44^{\mathrm{c}}$ \\
Inner plexiform layer & $21.8 \pm 0.69^{\mathrm{a}}$ & $22.3 \pm 0.71^{\mathrm{ab}}$ & $23.2 \pm 0.88$ & $25.4 \pm 1.27^{\mathrm{c}}$ \\
Ganglion cell layer & $17.6 \pm 0.53^{\mathrm{a}}$ & $11.2 \pm 0.61^{\mathrm{b}}$ & $7.7 \pm 0.89^{\mathrm{c}}$ & $5.9 \pm 0.71^{\mathrm{d}}$ \\
\hline
\end{tabular}

* Differences among the experimental groups were significant at this level. Values in the same column not sharing common superscript letters are significantly different $(P<0.05)$. Thirty individuals were assessed for each group; means \pm SD. 


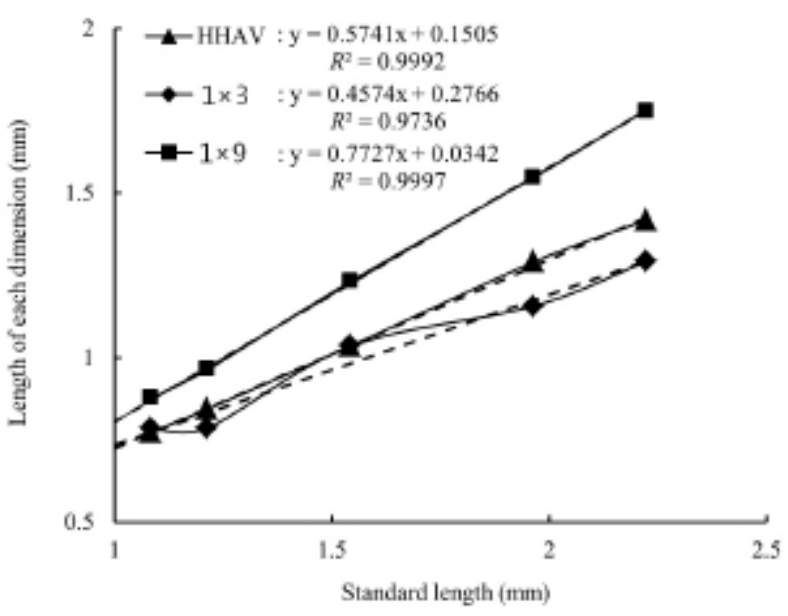

Fig. 4. The relationships between the standard length and the horizontal distance between the most anterior extension of the head and the anterior insertion of the ventral fin (HHAV), the most anterior extension of the head and the origin of the dorsal fin $(1 \times 3)$, and the most anterior extension of the head and the origin of the anal fin $(1$ $\times 9)$ in the cyprinid loach, Misgurnus anguillicaudatus, from hatching to 60 days after hatching. For abbreviations and each dimension, see Table 1 and Fig. 1.

just hatched to $50 \mathrm{DPH}(P<0.05)$. The major and minor axes of the proximal tubule cells in the kidney increased with time, and the minor axes of the proximal tubule cells were shorter than the major axes $(P<0.05)$. The surface area and volume of the proximal tubule cells in the kidney increased dramatically with time $(P<0.05)$.

Figures 5 and 6 shows the histological changes in the eye, kidney, and midgut epithelium of the cyprinid loach from just hatched to $50 \mathrm{DPH}$. The post-hatching eye shows a much looser layer structure than that in the eye at $50 \mathrm{DPH}$ (Fig. 5). The RCL structure is particularly

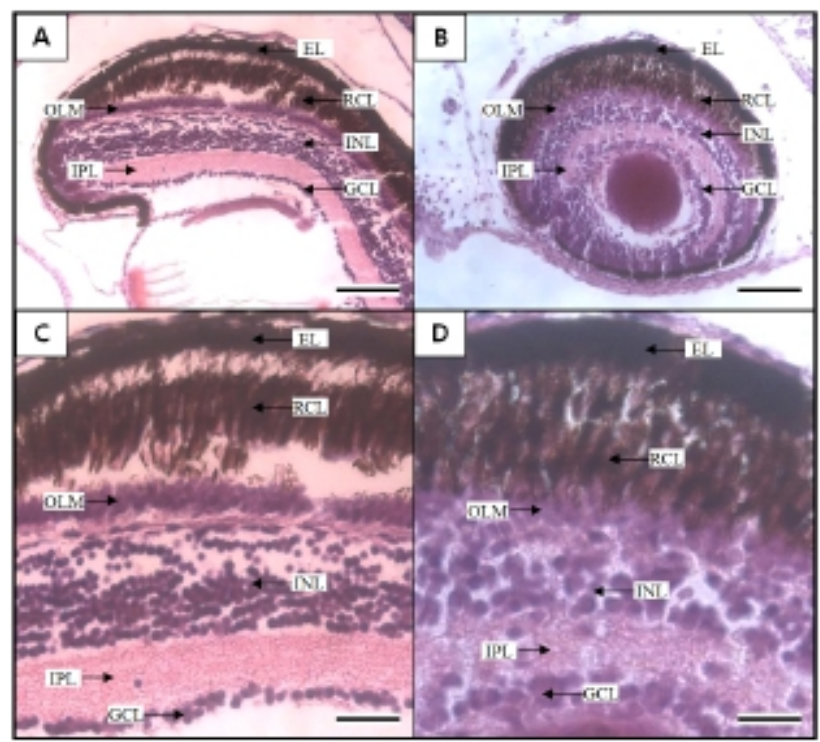

Fig. 5. Histological sections of the eye of the cyprinid loach, Misgurnus anguillicaudatus. A: Eye at hatching; B: eye at 50 days posthatching (DPH); C: high-power view of the eye at hatching; D: high-power view of eye at 50 DPH. EL: epithelial layer; GCL: ganglion cell layer; INL: inner nuclear layer; IPL: inner plexiform layer; OLM: outer limiting membrane; RCL: rod and cone layer. Each histological section was stained with $\mathrm{H} \& \mathrm{E}$. Bars in $\mathrm{A}$ and $\mathrm{B}$ indicate $100 \mathrm{~mm}$; bars in $\mathrm{C}$ and $\mathrm{D}$ indicate 10 .

Table 5. Size of proximal tubule cells in the kidney and nuclear height of the midgut epithelial cells in the cyprinid loach, Misgurnus anguillicaudatus, from hatching to 50 days after hatching*

\begin{tabular}{|c|c|c|c|c|}
\hline & \multicolumn{4}{|c|}{ Days after hatching } \\
\hline & 0 & 10 & 30 & 50 \\
\hline Nuclear height of midgut epithelium ( ) & $4.4 \pm 0.47$ & $7.5 \pm 1.91^{\mathrm{a}}$ & $9.1 \pm 2.05$ & $10.4 \pm 2.33^{c}$ \\
\hline \multicolumn{5}{|c|}{ Proximal tubule cell of kidney } \\
\hline Major axis ( ) & $3.3 \pm 0.33^{\mathrm{a}}$ & $4.1 \pm 0.42^{\mathrm{b}}$ & $7.0 \pm 0.74^{\mathrm{c}}$ & $10.5 \pm 1.80^{\mathrm{d}}$ \\
\hline Minor axis ( ) & $2.5 \pm 0.40^{\mathrm{a}}$ & $3.3 \pm 0.31^{\mathrm{a}}$ & $4.7 \pm 0.44^{\mathrm{ab}}$ & $7.7 \pm 0.58^{\mathrm{b}}$ \\
\hline Surface area $\left({ }^{2}\right)$ & $7.7 \pm 0.44^{\mathrm{a}}$ & $11.9 \pm 0.76^{\mathrm{b}}$ & $25.8 \pm 3.61^{\mathrm{c}}$ & $63.5 \pm 5.89^{\mathrm{d}}$ \\
\hline Volume ( 3 & $10.8 \pm 1.44$ & $\angle 3.4 \pm$ L.১১ & $8 U . y \pm y .11 c$ & $325.4 \pm 20.14^{\mathrm{d}}$ \\
\hline
\end{tabular}

* Differences among the experimental groups were significant at this level. Values in the same column not sharing common superscript letters are significantly different $(P<0.05)$. Thirty individuals were assessed for each group; mean \pm SD. Surface area $=1 / 4 \times$ ab $\pi$ and volume $=4 / 3 \times \pi(a / 2) \times(b / 2)^{2}$ (where $a=$ the major axis of a cell or nucleus; $b=$ the minor axis of a cell or nucleus; after Park $\&$ Kim, 2000). 


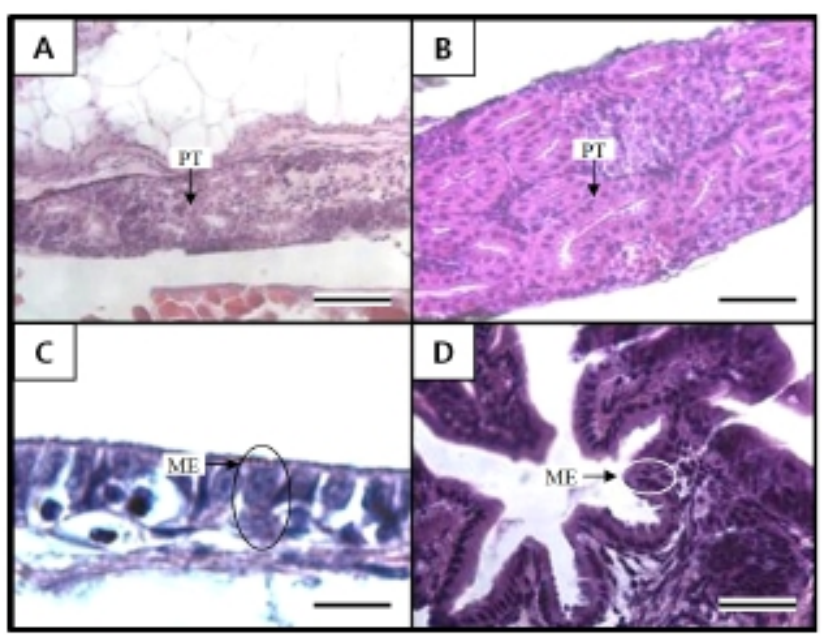

Fig. 6. Histological sections of the kidney and the midgut epithelium of the cyprinid loach, Misgurnus anguillicaudatus. A: Kidney at hatching; B: kidney at 50 days posthatching (DPH); C: midgut epithelium at hatching; D: midgut epithelium at $50 \mathrm{DPH}$. ME: midgut epithelium; PT: proximal tubule. Each histological section was stained with H\&E. Bars in A and B indicate $100 \mathrm{~mm}$; bars in C and $\mathrm{D}$ indicate 10 .

loose in the just-hatched eye, although it is densely concentrated at $50 \mathrm{DPH}$. The kidney consists of many proximal tubules (PT), appearing as hollow ovals and circles. At 50 DPH (Fig. 6B), the kidney has more and larger PT than the just-hatched kidney (Fig. 6A). The greatest change in the three tissues examined occurred in the midgut epithelium during the 50 days of the experiment. The midgut epithelium in the just-hatched larvae (Fig. 6C) is stretched and straight, whereas at $50 \mathrm{DPH}$ (Fig. 6D), it is wrinkled and folded, and the tissue has also become very dense (Fig. 6D).

\section{DISCUSSION}

The truss dimensions are the primary units of classification for the external anatomical markers that are normally assessed in fish (Sträuss \& Bond, 1990). The truss dimensions are length measurements that refer to the ratios between the width of the fish's body and the axis of the fish's length. Theoretically, the truss dimensions are a better measurement of the fish's shape than the classical dimensions (Sträuss \& Bookstein, 1982; Currens et al., 1989).

The combined morphometric traits of the cyprinid loach, Misgurnus anguillicaudatus, showed a tendency to increase from $20 \mathrm{DPH}$ to $60 \mathrm{DPH}$ (Table 3). However, $2 \times 10$ and $3 \times 10$ in the abdominal section showed some reduction with the absorption of the yolk sac. In this study, the day upon which the yolk sac was completely absorbed coincided with the reduction in $2 \times 10$ and $3 \times 10$ in the abdominal section. HHAV, HHAA, and HDMC increased during the experimental period (Table 3), which suggests that after hatching, the body length increased with time, although the shape and ratios described by HHAV, HHAA, and HDMC did not change significantly $(P>0.05)$. Consequently, during the early growth of the cyprinid loach, the horizontal dimensions decreased significantly.

In research related to the early growth of $M$. anguillicaudatus, it has been unclear when the whole yolk sac is absorbed and the larva begins to emerge, and there has been no information on how the shape of the yolk sac changes as it decreases in size as it is absorbed. In this study, YL decreased with time. After hatching, YH also decreased but the decrement was smaller than that of YL. We found that the decrement in YL was greater than that in $\mathrm{YH}$. Consistent with the reductions in $\mathrm{YL}$ and $\mathrm{YH}, \mathrm{YV}$ also declined, and the decrement in $\mathrm{YV}$ was the greatest among the three measures. This reduction in YV means that like alevin, the endogenous feeding of the juvenile is diverted to exogenous feeding as the yolk sac diminishes (Zhang et al., 1955; Dill, 1969, 1977; Brannon, 1972).

In the Teleostei, the eye usually continues to grow in the adult period, but the optic characteristics of the eye component stabilize in the early days of development. The eye of the cyprinid loach was completely formed after hatching. Its retina is composed of six layers (EL, INL, INL, IPL, OLM, and RCL), and each layer shows similar characteristic to those of other cyprinid fish (Takashi, 1982) (Fig. 5A, 5B). In this study, OLM in the cyprinid loach did not change significantly $(P>0.05)$, but there 
was a significant change in RCL $(P<0.05)$. This result is consistent with the study of Park \& Kim (2000). Similar research has also been conducted in the dark-banded rockfish, Sebastes intermis, and reported that unlike the cyprinid loach, RCL in the dark-banded rockfish does not change significantly during development $(P>0.05)$, although there is a significant change in OLM $(P<0.05)$ (Park et al., 2012). These changes are completely opposite those observed in the cyprinid loach. Based on these results and the intrinsic functions of the retinal components, we infer that the rates of change in the retinal components of a fish are related to the physiological ecology of the fish in the early days of its development.

The early development of the internal organs is consistent across most Teleostei (Blaxter, 1988). Generally, the kidney displays one of two types of developmental processes, forming either after hatching or before hatching. In this study, the kidney and PT were already formed when the fish hatched and developed completely during the first $50 \mathrm{DPH}$. This also occurs in the dentex, Dentex dentex, and like the cyprinid loach, the kidney of dentex is already formed when the fish hatches and grows continuously after hatching (Santamaria et al., 2004). As mentioned by Park \& Kim (2000), the major axes of the proximal tubule cells in the kidney of the cyprinid loach is $39.06 \pm 2.98$, and the minor axes and surface area are $31.38 \pm 2.04$ and $954.7 \pm 2.98$, respectively. In the previous study, the cyprinid loach was examined 10 months after hatching, whereas the samples in our study were examined at $50 \mathrm{DPH}$. Therefore, the combined results of Park and Kim (2000) and this study suggest that the kidney of the cyprinid loach continues to develop after $50 \mathrm{DPH}$.

It is generally reported that the absorptive function of the alimentary canal in fish is initiated either before or after the absorption of the yolk sac. In juvenile Coregonus fera, the yolk sac is completely absorbed after $11 \mathrm{DPH}$, and during this period, the absorptive function of the midgut epithelium begins to function (Loewe \& Eckmann, 1988). In the juvenile summer flounder, Paralichthys dentatus, the yolk sac is completely absorbed after 3 $\mathrm{DPH}$, and at $4 \mathrm{DPH}$, the absorptive function of the midgut epithelium begins to function (Bisbal \& Bengtson, 1995). However, in the juvenile pike eel, Muraenesox cinereus, the absorptive function of the midgut epithelium begins at $3 \mathrm{DPH}$, before the complete absorption of the yolk sac. At this time, although the mucosal fold in the midgut is not formed, microvilli structures can be detected in the midgut with optical microscopy and the active absorption of horseradish peroxidase was detected in these cells. Thus, liquefactive nutriments are presumed to be absorbed at this time (Otake et al., 1995). The midgut of the cyprinid loach is already present when it hatches and grows gradually to $50 \mathrm{DPH}$. Because the yolk sac in this fish is completely absorbed by $14 \mathrm{DPH}$, the absorptive function of the midgut is thought to begin before the yolk sac is completely absorbed, as in the pike eel.

As mentioned above, there has been insufficient research into the early growth of the cyprinid loach. In this study, the histological changes, morphometric characteristics, and absorption of the yolk sac were investigated during the experimental period from $1 \mathrm{DPH}$ to $60 \mathrm{DPH}$. Studies that correlate the different aspects of the early growth of the cyprinid loach, based on the results of this research, must be conducted.

\section{ACKNOWLEDGMENTS}

This work was funded by the Conservation and Restoration of Fish Species for Aquaculture (RP-2013-AQ-142) from the Inland Aquaculture Research Center, National Fisheries Research \& Development Institute (NFRDI), Korea. The authors thank the technical staff of the Inland Aquaculture Research Center, NFRDI, Korea, and the Laboratory for Fishery Genetics and Breeding Science at Korea Maritime and Ocean University (KMOU), Korea, for their helpful support, and the anonymous reviewers who greatly improved the quality of this manuscript. All procedures used in this study complied with the Research Ethics Guidelines of KMOU and the current laws of Korea (Ordinance of 
Agriculture, Food and Fisheries, No. 1, and the Law Pertaining to Experimental Animals, No. 9932).

\section{REFERENCES}

Bisbal GA, Bengtson DA (1995) Development of the digestive tract in larval summer flounder. J Fish Biol 47:277-291.

Blaxter JHS (1988) Patterns and variety in development. Hoar WS, Randall DJ (eds), Fish Physiology, Academic Press, New York, 11:1-58 pp.

Blaxter JHS, Hempel G (1963) The influence of egg size on herring larvae (Clupea harengus). J Cons Perm Int Explor Mer 28:211-240.

Brannon EL (1972) Mechanisms controlling migration of sockeye salmon fry. Internat Pacif Salmon Fish Comm Bull 21:86.

Currens KP, Sharpe CS, Hjort R, Schreek CB, Li HW (1989) Effect of different feeding regimes on the morphometrics of chinook salmon Oncorhynychus tshawytscha and rainbow trout, Oncorhynchus mykiss. Copeia 3: 689-695.

Dill LM (1969) The sub-gravel behaviour of Pacific salmon larvae. Northcote TG (ed). Symposium on Salmon and Trout in Streams, H.R. MacMillan Lectures in Fisheries, 1968, University of British Columbia, Vancouver, pp 89-99.

Dill PA (1977) Development behaviour in alevins of Atlantic salmon, Salmo salar and rainbow trout, $S$. gairdneri. Anim Behav 25:116-121.

Hubbs CL, Lagler KF (1947) Fishes of the Great Lakes region. Cranbrook Instit Sci 26:186.

Ihssen PE, Booke HE, Casslman JM, McGlade JM, Payne NR, Utter FM (1981) Stock identification: materials and methods. Can J Fish Aquat Sci 38:1838-1855.

Loewe H, Eckmann R (1988) The ontogeny of the alimentary trac of coregonid larvae: normal development. J Fish Biol 33:841-850.

Lythgoe JN (1979) The Ecology of Vision. Clarendon Press, Oxford, pp 1-261.
Nelson JS (2006). Fishes of the World (Fourth Edition). New Jersey: John Wiley \& Sons, Inc., Hoboken. p 146. O’Connell CP (1976) Histological criteria for diagnosing the starving condition in early post yolk sac larvae of the northern anchovy, Engraulis mordax Girard. J Exp Mark Biol Ecol 25:285-312.

Otake T, Hirokawa J, Fujimoto H, Imaizumi K (1995) Fine structure and function of the gut epithelium of pike eel larvae. J Fish Biol 47:126-142.

Park I-S, Im JM, Ryu DK, Nam YK, Kim DS (2001) Effect of starvation on morphmetric changes in Rhynchocypris oxycephalus (Sauvage and Dabry). J Appl Ichthyol $17: 277-281$.

Park I-S, Im SY, Hur JW, Jeong GS (2006a) Early growth and development of eye in dotted gizzard shad, Konosirus punctatus. Dev Reprod 10:93-96.

Park I-S, Kim DS (2000) Comparison of some tissues in diploid and triploid hybrid between mud loach, Misgurnus mizolepis and cyprinid loach, M. anguillicaudatus. Dev Reprod 4:19-28.

Park I-S, Nam YK, Kim DS (2006b) Grow performance, morphometric traits and gonad development of induced reciprocal diploid and triploid hybrids between the mud loach (Misgurnus mizolepis) and cyprinid loach (Misgurnus anguillicaudatus). Aquacult Res 37:12461253.

Park I-S, Park HJ, Gil HW, Goo IB (2012) Early growth and characteristic of histological eye development in post parturition dark banded rockfish, Sebastes inermis. Dev Reprod 16:101-106.

Park I-S, Seol DW, Cho SH, Song YC, Choi HJ, Noh CH, Myoung JG, Kim JM (2006c) Morphogenesis of the eye of brown croaker (Miichthys miiuy). Ocean Polar Res 28:287-290.

Park I-S, Woo SR, Song YC, Cho SH (2007) Effects of starvation on the morphometric characteristics of olive flounder, Paralichthys olivaceus. Ichthyol Res 54:297302.

Riddell BE, Leggett WC, Saunders RL (1981) Evidence of adaptive polygenic variation between two populations 
of Atlantic salmon, Salmo salar native to tributaries of the SW Miramichi river, NB. Can J Fish Aquat Sci 38:321-333.

Rodriguez A, Gisbert E (2001) Morphogenesis of the eye of Siberian sturgeon. J Fish Biol 59:1427-1429.

Santamaria CA, M Marin de Mateo, Traveset R, Sala R, Grau A, Pastor E, Sarasquete C, Crespo S (2004) Larval organogenesis in common dentex, Dentex dentex L. (Sparidae): histological and histochemical aspects. Aquaculture 237:207-228.

Sträuss RE, Bond CE (1990) Taxonomic methods, morphology. Methods for fish biology, American Fish Society, Bethesda, MD, USA. pp 125-130.

Sträuss RE, Bookstein FL (1982) The truss: body from reconstructions in morphometrics. Syst Zool 31:113-135.

Strussmann CA, Takashima F (1990) Hepatocyte nuclear size and nutritional condition of starved pejerrey, Odontesthes bonariensis (Cuvier et Valenciennes). J Fish Biol 36:59-65.
Takashi H (1982) An Atlas of Fish Histology. Kodansha Ltd, Tokyo, p 147.

Taylor EB, McPhail JD (1985) Variation in burst and prolonged swimming performance among British Columbia populations of coho salmon, Oncorhynchus kisutch. Can J Fish Aquat Sci 42:2029-2033.

Theilacker GH (1978) Effect of starvation on the histological and morphological characteristics of jack mackerel, Trachurus symmetricus larvae. Fish Bull USA 76: 403-414.

Wagner HJ (1990) Retinal stucture of fishes. Douglas R and M Diamgoz, The Visual System of Fish. eds. Chapman and Hall, London, pp 109-157.

Walls GL (1942) The Vertebrate Eye and Its Adaptive Radiation. Facsimile edition, Hafner Publishing Co, New York, pp 1-302.

Zhang CI, Sohn MH, Seong KB, Park I-S (1995) Yolk absorption and growth of chum salmon, Oncorhynchus keta alevin. Kor J Fish Aquat Sci 28:539-548. 